\title{
Utilizing Fish Bone into Economic Value Products Based Zero Waste in Semayan Village
}

\author{
Baiq Rani Dewi Wulandani ${ }^{1}$, Maesa Dita Ulpiana ${ }^{2}$, Ema Ratnasari ${ }^{3}$, Iin Shafira Dwiningtyas ${ }^{4}$ \\ ${ }^{1}$ Animal Husbandry Study Program, Faculty of Animal Husbandry, University of Mataram, Mataram, Indonesia \\ ${ }^{2}$ International Relations Study Program, Faculty of Social and Political Sciences, University of Mataram, Mataram, Indonesia \\ ${ }^{3}$ Accounting Study Program, Faculty of Economics, Mataram University, Mataram, Indonesia \\ ${ }^{4}$ Civil Engineering Study Program, Faculty of Engineering, Mataram University, Mataram, Indonesia
}

Email address:

baiq.rani@unram.ac.id (B. R. D. Wulandani), ditaulpiana15@gmail.com (M. D. Ulpiana), emaratnasari0900@gmail.com (E. Ratnasari), Inshafira1003@gmail.com (I. S. Dwiningtyas)

\section{To cite this article:}

Baiq Rani Dewi Wulandani, Maesa Dita Ulpiana, Ema Ratnasari, Iin Shafira Dwiningtyas. Utilizing Fish Bone into Economic Value Products Based Zero Waste in Semayan Village. American Journal of Environmental and Resource Economics.

Vol. 6, No. 3, 2021, pp. 86-90. doi: 10.11648/j.ajere.20210603.12

Received: August 11, 2021; Accepted: August 23, 2021; Published: August 31, 2021

\begin{abstract}
Utilization of fish bones into products with economic value is one part of the program zero waste which aims to minimize fish bone waste in Semayan Village, Praya District, Central Lombok Regency, Indonesia. The large amount of fish bone waste in Semayan Village is due to the fact that most people work as fishermen and cultivate freshwater fish. However, fish bones caught are rarely used and become waste that is sometimes thrown away around the dam. Seeing these problems, the author has an innovation to process fish bones into fish bone crackers and fish bone meal. The method used is explanation and training. Where will explain to the residents the benefits of fish bones that are not widely known and provide hands-on training to make products. The results obtained are fish bone crackers and fish bone meal products that have been processed with the community. The product will have economic value if it is developed by the community. In addition, from crackers and fish bone meal products will form a joint business group in the Semayan community which has not yet been formed. And reduce environmental pollution due to household waste including fish bone waste in the Semayan environment. Thus, the purpose of utilizing fish bones into products of economic value based on and reduce environmental pollution due to household waste including fish bone waste in the Semayan environment. Thus, the purpose of utilizing fish bones into products of economic value based on And reduce environmental pollution due to household waste including fish bone waste in the Semayan environment. Thus, the purpose of utilizing fish bones into products of economic value based onzero waste properly achieved.
\end{abstract}

Keywords: Fishbone, Economical, Zero Waste, Semayan

\section{Introduction}

Semayan is one of the villages in the Praya sub-district, what can be done from fish bone waste in Semayan village is wrong Central Lombok Regency, West Nusa Tenggara Province. Area the Semayanclose by with Batu Jai Dam which is the largest dam in the Regency Fish crackers are one type Lombok make Semayan Jai Batu stone Middle. That matter local communinity take advantage of the dam Batu Jai stone for fish ponds for residents who are cultivating freshwater fish. Freshwater fish cultivation in the
Semayanarea is quite a lot so that the amount of freshwater fish available is also large. The number of available freshwater fish makes people in the Semayan area sometimes use the fish as a side dish or even make a product in the form of shredded fish. However, on the other hand, fish bones left over from the manufacture of shredded or sisal auk pauk are sometimes simply thrown away by the Semayan people so that they become garbage or waste in the Semayan environment.

In order not to become or waste, it is necessary the development of one of the potentials of the Semayan area in the form of fish bones from the processing of freshwater fish 
products and leftover side dishes, willdirected to on draft zero waste. Zero waste the covers process for maximizing recycling, minimize waste, and ensure a product can be recycled so that the waste generated close to zero. Zero what can be done from fish bone wate in Semayan village is wrong the only one by utilizing wate the become product worth economical like shrimp crisp fish bones and flour.

Fish crackers are one type of snack that is well known by the public and is usually used as food to accompany rice. Fish crackers have a delicious and savory taste so they are liked by many people from various walks of life. Besides being able to be eaten as snacks, crackers can also be made into snacks, with this it can provide added value for both the cracker manager and the village because it can increase economy, and able to compete with other products in the market. In addition, the process of making fish crackers is quite simple, so it can be used as a main or side business for the family. Utilization of waste into flour for artificial feed and fish bone crackers is considered as one solution to improve the village economy and reduce waste. Quality fish bone flour can not only be seen from the amount, but also from the nutritional value including protein, fat, and minerals. So that with the presence of artificial feed made from food waste, besides being able to lighten the burden on the community in purchasing feed as well as provide solutions in reducing organic waste so that Semayan village as an area zero waste can be realized. In addition, freshwater fish bones contain many nutrients that the body needs such as protein, fat, calcium, vitamin C, vitamin A, sodium, and iron. Therefore, in the form of fish in capable minimize fish bone waste in the Semayan and products that have economic value.

\section{Utilization of Fish Bones into Crackers and Flour Fishbone}

In program work the first thing to do is to provide information to the Semayan village community that the first thing to do is make crackers and fish bone meal the benefits of fish bone waste for healt, economy and environment. Activity the realized in the form of workshops and training for the Semayanvillage community. Furthermore, it is necessary to prepare in advance the tools and production materials to carry out the processing.

\subsection{Forms of Activities}

Form whole activity by in utilize fish bones into a zerowaste-based economic value product in the Semayan village, namely:

Program preparation

Village potential survey

From fish bones (crackers and flour) Product manufacturing trial

Bone product production fish

Product Training making

\subsection{Time and Place}

The implementation of making crackers and fish bone meal starts from June to August 2021, taking place in the Semayan Environment, Semayan Village, Praya District, Central Lombok Regency, West Nusa Tenggara Province.

\subsection{Product Creation Workflow}

Digital scales
Gloves
Knife
Pan
Blender
Presto
Stove
Saltwater
Freshwater Fish Bones
Flavoring
Onion and Bottom White
Banana Leaf

2.3.1. Tools and Materials for Making Fishbone Flour

Digital scales

Gloves

Knife

Pan

Blender

Presto

Stove

Saltwater Freshwater Fish

Bones

Freshwater Fish Bones

After conducting training and preparing tools and materials, the next step will be the product manufacturing process. But first, residents who take part in the manufacturing process will be divided into several groups according to the number of people participating. The group will process each product that has been described in the workshop and training. The processing process starts from preparation to marketing product.

\subsubsection{Flow Work Making Fish Bone Products}

The workflow carried out in making Fish Bone Crackers is first, fish bones cleaned then boiled until the texture is not hard anymore. After that, the fish bones are blended until they become like mush. Fish bones that have been blended mixed with the spices that have been prepared. Next, pour kg of tapioca flour and $1 \mathrm{~kg}$ of wheat flour into the fish bone porridge. Pour in the mineral water while stirring by hand to get a less dense result. After that, the mixture is poured into an open mold which is used as a steamer to form a fish bone crackers before drying. Next done drying by drying for 2 days then packed into good packaging. [1]

The workflow carried out in the manufacture of Fish Bone Flour is first, fish bones cleaned then boiled until the texture is not hard anymore. Furthermore, the fish bones are dried in the sun for 23 days until they are completely dry. Then grind using a blender. After that, it is dried again to reduce the fishy 
smell in the packaging for 1 day. Next, the packaging process is carried out properly. [2]

\section{Results and Discussion}

Utilization of fish bones into economically valuable products based on zero waste in KelurahanSemayan started with survey activities regarding the problems that exist in the kelurahan and the potential possessed by the Semayankelurahan. By looking at one of the problems that exist in the Semayan village, namely the silting of the dam due to several causes, such as the number of residents who Dispose of garbage or household waste around the dam, one of which is fish bone waste, and there is a fish called snakehead fish by the Semayan people rarely. Utilized by because that, look these problems and one of the potentials in the Semayan village is freshwater fish farming. Thus, the use of fish bones into products of economic value based onzero waste will reduce the disposal of household waste, one of which is fish bones around the dam in the Semayan area centered on the Batu Jai Dam.

\subsection{Product Overview}

Fish bones are part of the body of fish that often become food waste and are thrown away or become cat or dog food. [3] Its hard texture makes it difficult for the mouth to digest and sometimes makes the throat hurt if eaten just like that. However, behind this, it turns out that fish bones have some benefits especially for health. This is because there are several nutrients contained in fish bones. Fish bones contain some calcium as the main component of the formation of bones and teeth. [11] Contains phosphorus and carbonate as joint strengthening and muscle pain relievers. The calcium content in fish bones varies depending on the type of fish. [4] In addition to the main content in the form of calcium. Fish bones also contain protein, phosphorus, and iron. [12] Thus, fish bones are very beneficial for the health of the body. In addition, fish bones can be processed into several food products. [5] This is because fish bones contain high minerals, most of which contain calcium and phosphorus which are needed by the body. Diversification that foods with calcium that meet the needs of the human body is one of the efforts to meet calcium needs for humans. [6] Food diversification can be done by make the kind of food contains high calcium from utilization of calcium contained. [7] in fish bones. Food products that can be produced from fish bones are fish bone crackers and fish bone meal. [13]

\subsection{Making Products from Fish Bone}

a. Stages of Making Fish Bone Crackers

Clean use flow.

Boil the fish bones for up to 20 minutes, so that they can be blended.

Blend the fish bones until they are smooth into fish bone pulp.

Prepare tablespoon salt, 1 tablespoon food crumbs, 1 tablespoon backing soda, 2 packs of paprika, 2 packs of masako.

Mix with fish bone porridge.

Mix $\mathrm{kg}$ tapioca flour and $1 \mathrm{~kg}$ wheat flour into the fish bone porridge [14].

Add water to make the dough liquid.

Then pour the cracker mixture into the food heating container.

Next, cut the dough that has been formed into small sizes.

Dry crackers up to 2 days [15].

Do the packaging of crackers using the packaging that has been provided bone water fish that has been provided. [8]

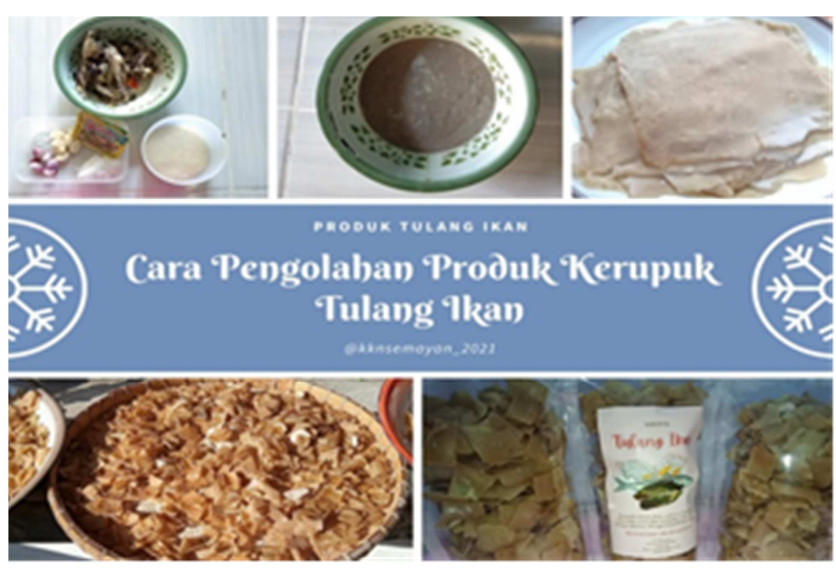

Figure 1. Bone Cracker Processing Fish.

b. Bone Flour Making Stage Fish

Clean use flow bone water fish which Figure.

Boil the fish bones for up to 20 minutes.

Dry the fish bones for up to 2 days until they are completely dry.

Puree the dried fish bones using a blender 5. [9] Package the crackers using.

Package the crackers using the packaging provided. [10].

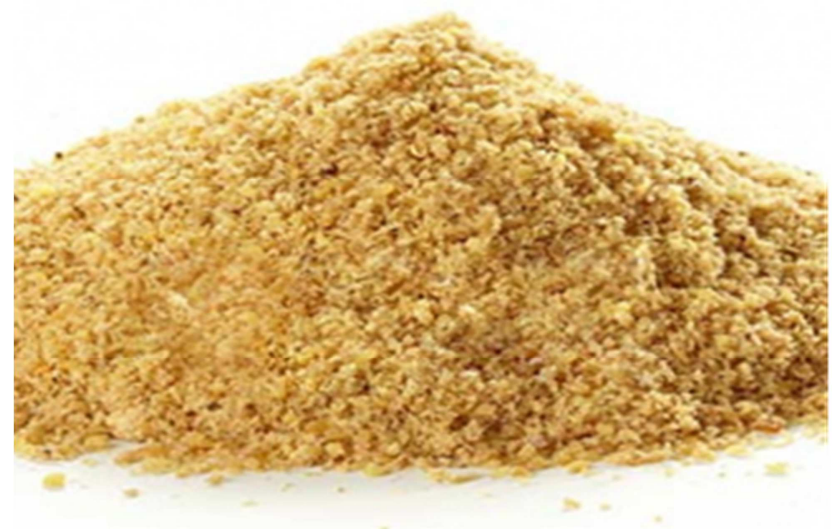

Figure 2. Fish Bone Flour.

\subsection{Price or Economic Value of Fish Bone Products}

a. Fish Bone Crackers

The selling price of fish bone crackers is $25,000 / \mathrm{kg}$. 


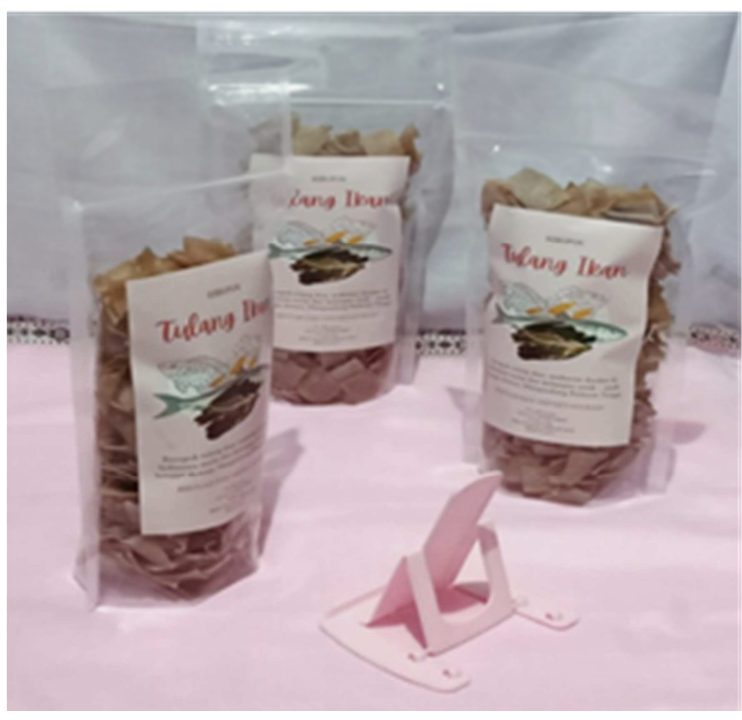

Figure 3. Fish Bone Crackers.

Fish Bone Flour.

The price of fish bone meal is $10,000 / 1$ pack.

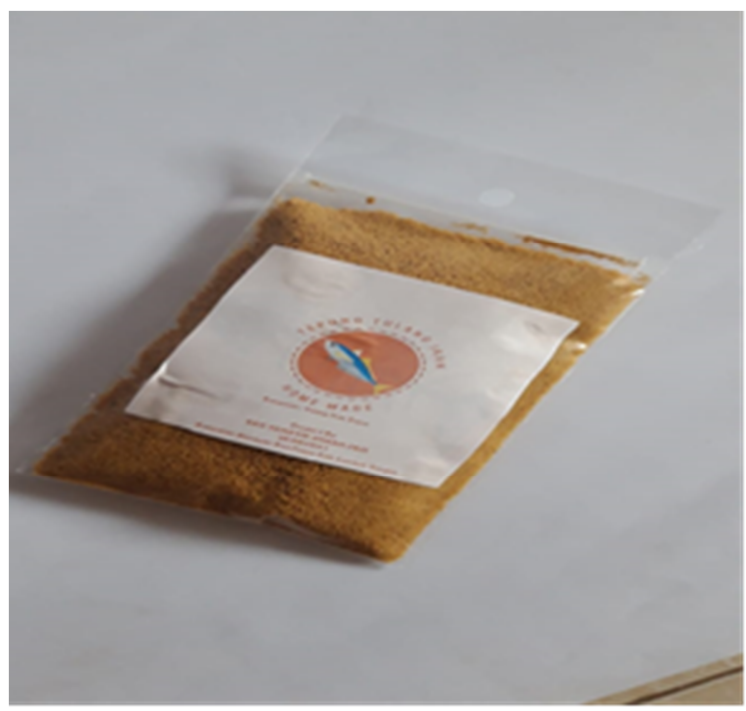

Figure 4. Fish Bone Flour:

\section{Conclusion}

Utilization of fish bones into economically valuable products based on zero waste in Semayan Village went well. This is evidenced by the enthusiasm of the community in participating in the training on processing fish bone products carried out by the Thematic Community Service Community Service Group 1 Mataram University 2021. Fish bone crackers and flour products Fish bones are considered as a new innovation by the people of Semayan that can add jobs and business groups in the community. So that after the training, there were several residents who produced their own fishbone crackers at home, including the Head of the Semayan Environment. Therefore, fish bone products are very suitable to be developed in Indonesia Semayan Village because there are many people who cultivate freshwater fish and become fishermen. In addition, to reduce household waste disposed of by the community in the dam which will accelerate the deposition of the dam, this fish bone product is considered successful by the community. The Semayan community in the use of waste. So, for the sustainability of the product, the Semayan community or the thematic KKN group at the University of Mataram 2021 can continue. Regarding the selling price of the product, it depends on the production value used and also the packaging. And the marketing will be done directly and also through social media such as Facebook and Instagram as well as social media like market place.

\section{Acknowledgements}

We say thank you to public Semayan, Head Semayan Environment and Mrs. and Mr. Semayan Village staff who have assisted in the implementation of activities related to the utilization of fish bones into economically valuable products based on zero waste in the Semayan village. So that the activity runs properly without many obstacles. We also don't forget to thank the KKN Field Supervising Lecturers who have provide support and input on the products from fish bones that we produce. As well as the LPPM who have trusted us to carry out KKN activities in Semayan Village, Praya District, East Lombok Regency.

\section{References}

[1] [AOAC] Association of Official Analytical and Chemists. 1995. Official Methods of Analysis the 16th ed. Virginia: Inc. Arlington.

[2] Alais C, Linden G. 1991. London: Food Biochemistry. Ellis Harwood

[3] Allen LH, Wood JR. 1994. Calcium and phosphorus. In: Shils EM Olson JA, Shike M, editors. Modern Nutrition in Health and Diseases. Ed. 8 Vol 1. USA: Lea and Febringer.

[4] Almatsier S. 2002. Basic principles Science of nutrition. Jakarta: Main Library. PT. grammar.

[5] Apriyantono Puspitasari A, NL, Fardiaz D, Budiyanto S. 1989. Food Analysis. Bogor: Inter-University Center for Food and Nutrition, IPB.

[6] Beatrice MI. 2001. Studying the process of making honey flour using a spray dryer and the physical and chemical properties of the resulting flour. [Thesis]. Bogor: Postgraduate Program, IPB.

[7] Elfauziah R. 2003. Separation Calcium From Fish Head Bones catfish (Pangasius sp.). [script]. Bogor: Faculty of Fisheries and Marine Sciences, IPB.

[8] Fardiaz D, Andarwulan N, Wijaya H, Puspitasari NL. 1992. Hint Laboratory: Chemical Properties and Functional Component Analysis Techniques Food. Bogor: InterUniversity Center for Food and Nutrition, IPB, Directorate General of Higher Education, Ministry of Education and Culture. 
[9] Linder MC. 1992. Nutritional Biochemistry and Metabolism by Use Clinical. Jakarta: UI Press.

[10] Mulia. 2004. Study on the potential of catfish bone waste (Pangasius sp.) as an alternative source of calcium in dried noodle products. [Essay]. Bogor: Faculty of Fisheries and Marine Sciences, IPB.

[11] National Standardization Council. 1992. National Standard for Bone Flour. SNI 01-3158-1992. Jakarta: National Standardization Council.

[12] Steel RGD, Torrie JH. 1993. Principles and Procedures of
Statistics. In the Sumantri B, translator. Statistical Principles and Procedures. Jakarta: PT. Main Library Gramedia.

[13] Syarief R, Irawati A. 1988. Knowledge of Materials for the Agricultural Industry. Jakarta: Mediyatama Sarana Perkasa.

[14] Winarno FG. 1997. Food Chemistry and Nutrition. Jakarta: PT. Main Library Gramedia.

[15] Wirakartakusumah MA, Abdullah K, Sharif AM. 1992. Physical Properties of Materials Food. Bogor: Inter-University Center for Food and Nutrition, IPB, Directorate General of Higher Education, Ministry of Education and Culture. 